MARCIN POLAKOWSKI

Instytut Politologii UMK

\title{
Indywidualność jako kategoria filozofii Michaela Oakeshotta
}

I nie może już żyć człowiek, u którego zanikły pożądania

T H O M A $\mathrm{HO}$ B B E S ${ }^{1}$

$\mathbf{M}$

yśl Michaela Josepha Oakeshotta (1901-1990), chociaż uważa się go za jednego z najbardziej znaczących XX-wiecznych angielskich filozofów polityki, nie jest w centrum głównych sporów współczesnej refleksji filozoficzno-politycznej. Przez lata bardzo mało popularny i wywołujący swoimi pracami nikłe zainteresowanie ${ }^{2}$, nieco większą uwagę badaczy przyciągnął dopiero w ostatnich dekadach, głównie w Europie, w Stanach Zjednoczonych i Kanadzie ${ }^{3}$, kiedy dostrzeżono wartość jego głosu zarówno w debatach nad kondycją współczesnego państwa, jak i zauważając kompleksowość i oryginalność jego koncepcji.

\footnotetext{
${ }^{1}$ T. Hobbes, Lewiatan czyli materia, forma i władza państwa kościelnego i świeckiego, Warszawa 1954, s. 85.

2 J. L. Auspitz, Bibliographical Note, „Political Theory”, vol. 4, nr 3, 1976, s. 295-300. P. Śpiewak, Granice polityki, w: M. Oakeshott, Wieża Babel i inne eseje, Warszawa 1999, s. 17-20.

${ }^{3}$ Za Oceanem, dyskusje nad myślą Oakeshotta w naukowych periodykach amerykańskich i kanadyjskich rozpoczęły się dopiero w drugiej połowie lat 70., kontynuowane były głównie w pierwszej połowie lat 90., po śmierci myśliciela. Dziś myśl Oakeshotta zainteresowanie wzbudza głównie w Europie (u pojedynczych badaczy w różnych krajach), gdzie organizowane są cykliczne konferencje poświęcone jego dziełu. Patrz: http://www.michaeloakeshott-association.org/
} 
Trudno w krótkim szkicu przedstawić wielość tematów poruszanych przez Oakeshotta, nawet jeśli miałby on charakter stricte przeglądowy. Celem niniejszej pracy będzie raczej przedstawienie i wyróżnienie indywidualności, w nierozerwalnym powiązaniu z wolnością i wolą, jako jednej z podstawowych kategorii filozoficznych w koncepcjach Michaela Oakeshotta, wspornika jego głównych założeń z zakresu ontologii, a przede wszystkim podstawy sformułowanej przez niego wizji polityki i teorii państwa. Nawet tak skromny cel pozwala jedynie na prześwietlenie wybranych zagadnień i punktów z bogatej panoramy dorobku tegoż myśliciela. Jeśli zająć się znaczeniem pojęcia indywidualności i jego pochodnych, konieczne stanie się również choćby ogólne sklasyfikowanie i umiejscowienie teorii angielskiego myśliciela, o ile nie w odniesieniu do konkretnych doktryn czy ideologii, o tyle chociaż - bardziej ogólnie - w stosunku do szerszych nurtów refleksji politycznej.

\section{Filozofia (polityki) a modalności doświadczenia}

Sprawą kluczową dla zrozumienia dzieła Oakeshotta jest niewątpliwie zaznajomienie się z jego poglądem na rolę refleksji filozoficznej w ogóle oraz w namyśle nad polityką. Chociaż stawia się go częstokroć w jednym szeregu obok Leo Straussa czy Erica Voegelina, jako odnowiciela klasycznego rozumienia filozofii polityki zepchniętej na margines spektrum refleksji nad polityką, jego stanowisko raczej nie koresponduje z klasycznym rozumieniem funkcji filozofii.

W eseju Filozofia polityki ${ }^{4}$ Oakeshott stawia ją jako najwyższą formę refleksji nad politycznością, różne rodzaje namysłu przedstawiając w obrazowej formie wieży, w której zależnie od piętra, z którego dokonuje się obserwacji, można dostrzec więcej lub mniej niuansów i szczegółów krajobrazu. „Świat widziany z parteru to świat, od którego wychodzi wszelka refleksja. W miarę jednak, jak postępujemy ku górze, widok ulega zmianie: wspinając się, zaczynamy dostrzegać rzeczy, które wcześniej były niewidzialne, i na każdym piętrze objawia się nam nowy świat"5. I tak najwyższe piętro stanowi filozofia, w odniesieniu do polityki, rzecz jasna, filozofia polityki: „filozof jest gotów iść dalej, gdy inni będą już radzi się zatrzymać"6. Oakeshott największą wartość filozofii dostrzega w jej autokrytycyzmie, antydogmatyzmie, w braku wewnętrznych niekwestionowalnych założeń i podstaw, co pozwala nazywać ją działalnością radykalnie burzycielską.

\footnotetext{
${ }^{4}$ M. Oakeshott, Filozofia polityki, w: tegoż, Wieża Babel..., s. 119-138.

Tamże, s. 124.

${ }^{6}$ Tamże.
} 
Refleksja „na najwyższym piętrze - piętrze filozoficznym”, uszczegóławia ubogie obrazy z pięter niższych czy może raczej pozwala dostrzec rzeczy niżej niemożliwe do dostrzeżenia tak, iż faktycznie tworzy obraz od nowa, pozwala spojrzeć nam na horyzont z zupełnie innego punktu widzenia i w nowy, fascynujący sposób, stare zastępując zupełnie nowym. Właśnie to nieskrępowanie jest istotą filozofii, również w jej aspekcie politycznym ${ }^{7}$. Pewność i poczucie wartości dokonywanych rozważań, nie może jednak ich zdominować. Kiedy tak się dzieje filozofia zatraca swoją istotę - łatwo może stać się refleksją „w służbie polityki” lub działalnością refleksyjną nastawioną na skonstruowanie czegoś, co „można nazwać doktryną polityczną".

Oakeshott - w odróżnieniu od Leo Straussa - nie uważa, że filozofia polityki winna być działalnością poszukującą podstawowych odpowiedzi na to, czym jest prawda i dobro w kontekście polityczności. Nie wydaje się, by filozofia polityki - jak w wizji straussowskiej - opinię o rzeczach politycznych miała i mogła zastąpić wiedzą, jeśli już, to co najwyżej niewyraźny obraz może wyostrzyć, ale nie posiada na to wyłączności. Choć Oakeshott podziela ze Straussem ogląd filozofii jako tej, która w przeciwieństwie do niższych form refleksji nad polityką nie ogranicza się do tworzenia ram zamkniętych systemów, nie podlegających krytycznemu namysłowi, proponujących nam nieweryfikowalne przekonanie, twardy mit ${ }^{9}$, to jednak nie nadaje jej przymiotu kształtowania porządku normatywnego. „Filozofowie (...) znają pewne odmiany ekspresji, rozróżniają też rozmaite tony wypowiedzi, ale słyszą tylko jeden autentyczny głos (...) wciąż trzyma się mocno pogląd, że w wieży Babel obłożono ludzkość klątwą, a zadaniem filozofów jest uwolnić nas od niej"10.

Oakeshottowska koncepcja filozofii od samego początku jego kariery jest zasadniczo sceptyczna. Stawiając w centrum ludzkie doświadczenie, czyli zespół wrażeń, myśli i intuicji, wyróżnia cztery modalności jego interpretacji: historię, naukę, praktykę i poezję ${ }^{11}$. Modalności nie są wycinkiem doświadczenia, „nie są tylko koherentnymi dziedzinami ludzkiej działalności, bo w istocie, nazywanie ich «dziedzinami» wskazuje na mylącą

\footnotetext{
7 Tamże, s. 125.

${ }^{8}$ Tamże, s. 129

${ }^{9}$ L. Strauss, Czym jest filozofia polityki?, w: tegoż, Sokratejskie pytania. Eseje wybrane, Warszawa 1998, s. 63-64.

${ }^{10}$ M. Oakeshott, Poezja i jej głos w rozmowie ludzkości, w: tegoż, Wieża Babel..., s. 243.

${ }^{11}$ W swej pierwszej książce Experience and Its Modes (1933) Oakeshott wyróżnił trzy modalności: naukę, historię i praktykę. Wiele lat później dodał do nich poezję (1959). M. Oakeshott, Experience and Its Modes, Cambridge 1985, s. 69-80. J. L. Auspitz, Individuality, Civility, and Theory: The Philosophical Imagination of Michael Oakeshott, „Political Theory”, vol. 3, nr 4, 1976, s. 262.
} 
analogię"12. Każda modalność tworzy odrębny, autonomiczny sposób scalania potocznego doświadczenia ludzkiego (natomiast nie jest sposobem jego dzielenia), inny sposób jego transkrypcji, inne okno przez które patrzymy na świat $^{13}$. Każda z nich ma właściwe ku temu metody, sposób artykulacji i wewnętrzną dynamikę. Głos historii, poezji, nauki czy praktyki jest odrębną narracją, opowiada nam inną historię. Stosunki pomiędzy głosami są nienegocjowalne, każda modalność doświadczenia tworzy odrębny obraz, spójną całość, opartą na innych kategoriach interpretacyjnych. Oceny dokonywane na gruncie jednej modalności doświadczenia są nieadekwatne w stosunku do innych, zastosowane w ich obrębie przynoszą tylko błąd i pomieszanie. Nie sposób z ewentualnego zderzenia wyciągnąć wniosku o większej prawdziwości bądź fałszywości danego głosu w „rozmowie ludzkości”, choć $\mathrm{w}$ obrębie każdego z nich pojawiają się akcenty, przekonujące o jego wyjątkowości w tym zakresie. Jednak prawda sama w sobie ma sens tylko w konkretnym kontekście doświadczenia, musi być w nim zakorzeniona. Stwierdzić więc można jedynie do czego dana modalność bardziej się nadaje. I tak historia bada przeszłość na podstawie szczegółowej znajomości faktów, szuka wyjaśnień danych wydarzeń, poprzez zasypywanie faktograficznych dziur i budowanie ciągów przyczynowo-skutkowych. Nauka z kolei poszukuje powtarzalnych uogólnień w kwantytatywnym zapisie. Poezję można w pewnym sensie nazwać modalnością próżniaczą, skupioną na autotelicznej kontemplacji obrazów, wydarzeń, ludzkich charakterów, niedokonującą ani ciągłego kwestionowania ani aprobowania, powstrzymującą się od pokusy oceny. Dla diagnozy conditio humana, różnych sfer działania istoty ludzkiej, jej postępowania, właściwego oglądu instytucji, motywów, procesów, niewątpliwie największe znaczenie ma jednak doświadczenie praktyki. Wreszcie, to właśnie filozofię - odruch badania własności i stylu każdego głosu oraz refleksji na temat ich wzajemnych odniesień - nazywa Oakeshott działalnością pasożytniczą, jako że wyrasta z rozmowy, ale nic konkretnego do niej nie wnosi ${ }^{14}$. Filozofia, czyli krytyczny namysł, wskazuje na to, że żadna modalność nie może w pełni oddać bogactwa ludzkiego doświadczenia, jej zadaniem jest zadawanie pytań, wskazywanie na ograniczenia nauki, historii, praktyki i poezji ${ }^{15}$, pokazywanie, na jakich postulatach i założeniach zbudowany jest szkielet każdej modalności, bez których nie mogłaby ona istnieć, a które w jej ramach mają status niepodważalnych. Nie chodzi o to, by to filozofia odpowiadała nieomylnie, wyznaczała granice, w jakich obszarach

\footnotetext{
${ }^{12}$ J.L. Auspitz, Individuality..., s. 262.

${ }^{13}$ Tamże.

${ }^{14}$ M. Oakeshott, Poezja..., w: tegoż, Wieża Babel..., s. 246.

${ }^{15}$ Tenże, Experience..., s. 81-85.
} 
doświadczenia która modalność jest jedyną właściwą, bo przecież doświadczenie jest niepodzielne. Wierna jest więc filozofia sprzeciwowi wobec sprowadzania modalności do autorytatywnego obrazu całości doświadczenia, ale sama nie proponuje nic prócz radykalnego burzycielstwa. Napomina, nic sama nie proponując.

Taki obraz ludzkiego doświadczenia i filozofii ma iść według zamiarów Oakeshotta wbrew gnostyckim tendencjom myśli nowoczesnej, próbujących racjonalnie zbudować ogólną i metodyczną teorię polityki i ludzkiego postępowania. Rozmowa ludzkości, pojmowana jako realne wezwanie moralne wobec każdego człowieka, jak i jako alegoria teorii modalności polega na tym, że uczestnicy „nie prowadzą dociekań ani dyskusji; nie mają żadnej «prawdy» do odkrycia, żadnych twierdzeń do udowodnienia, żadnych konkluzji, których by szukali. Nie zależy im na tym, by się nawzajem informować, przekonywać lub obalać swoje twierdzenia; dlatego też siła ich wypowiedzi nie zależy od tego, czy wszyscy będą mówić w jednym języku; mogą się różnić, nie popadając w niezgodę"16.

Oakeshott w swojej filozofii polityki zdaje się stać na gruncie konstruktywistycznego modelu poznania, uważając, iż wiedza jest raczej konstruowana $\mathrm{w}$ społecznym procesie wytwarzania i historycznie przygodna ${ }^{17}$. Bardzo ostrożnie występuje $\mathrm{z}$ oceną czasów przednowoczesnych, podzielając przekonanie, że nasze oceny na temat dawnych dziejów z definicji muszą być zapośredniczone przez nowożytną wiedzę i nie są w stanie dokonać adekwatnego opisu tamtego świata $\mathrm{z}$ "boskiego punktu widzenia” bądź ze „spojrzenia znikąd”. W swojej filozofii skupia się więc raczej na diagnozie naszej rzeczywistości, jako punktu wyjścia dla poszukiwania rozwiązań, a nie na konstruowaniu modeli idealnego porządku społecznego.

\section{Hobbes - historia zerwania}

Tomasz Hobbes jest jednym z podstawowych źródeł inspiracji dla Oakeshotta i filozofem bardzo przezeń cenionym, któremu poświęcił najwię-

\footnotetext{
${ }^{16}$ Tamże, s. 244. Od chwili gdy w 1933 r., w wieku 32 lat, Oakeshott w książce Experience and Its Modes zarysował swoją teorię doświadczenia, modalności i filozofii do eseju The Voice of Poetry in the Conversation of Mankind, napisanym w roku 1959, minęło 26 lat. Wielu interpretatorów doszukuje się tutaj ewolucji stanowiska Oakeshotta, jego coraz bardziej sceptycznego ujęcia filozofii pod wpływem Wittgensteina i Heideggera. Wydaje się jednak, że poza wyróżnieniem poezji - jako nowej modalności - i ujęciem w iście poetyckim stylu dawnych poglądów, stanowisko Oakeshotta nie uległo większym zmianom.

${ }^{17}$ A. Zybertowicz, Przemoc i poznanie. Studium z nie-klasycznej socjologii wiedzy, Toruń 1995, s. 108 157.
} 
cej pism ${ }^{18}$. Na nim skupia się niemal od początku swojej pracy naukowej i z niego czerpie inspiracje, które później przeformułuje w swoje ostateczne stanowisko.

Największe znaczenie w myśli Hobbesa ma według Oakeshotta radykalne zerwanie z tradycyjnym, klasycznym racjonalizmem i koncepcją prawa naturalnego z niego wynikającą. „Nie ma bowiem takiego «finis ultimus» (ostatecznego celu) ani «summum bonum» (największego dobra), o jakich się mówi w księgach starych filozofów moralnych"19. Przełomowość Hobbesa polega na zastąpieniu prawa naturalnego uprawnieniem jednostki. Uprawnieniem tym zaś jest bezwarunkowa wolnośćc ${ }^{20}$. Tę „wolność poddaje się samoograniczeniu po to, by możliwe było stanowienie prawa" ${ }^{21}$. Woluntaryzm Hobbesa szczególnie ceniony przez Oakeshotta polega na tym, iż konieczna jest zgoda rządzonych, aby poddać się autorytetowi władzy, suwerenowi, woli prawodawczej. $Z$ natury zatem nie sposób wyprowadzić żadnego prawa, bo z natury mamy do czynienia tylko z wolnością człowieka ${ }^{22}$.

„Niewiele w istocie można uzyskać dzięki ogólnym spekulacjom na temat «natury ludzkiej», która nie jest bardziej trwała od innych znanych nam rzeczy. Większy sens miałoby zastanowienie się nad obecną naturą ludzką, nad nami samymi" ${ }^{23}$. Hobbes w dużym stopniu tak właśnie czyni. Dla Hobbesa rozum jest zawsze hipotetyczny, nigdy kategoryczny, dlatego nieudolny w nakładaniu zobowiązań i obowiązków ${ }^{24}$. To on jako pierwszy filozof najpełniej zawiera w swojej filozofii nominalistyczną, późnoscholastyczną zasadę individua substantia ${ }^{25}$. Wola jest podstawą organizmu państwowego i tylko ze zgody rządzonych winien wynikać autorytet i uprawomocnienie władzy. Oakeshott odrzuca kontraktualistyczny aparat pojęciowy i koncepcję umowy społecznej - pojmowane dosłownie wydają mu się naiwne i historycznie wyabstrahowane, zaś teoretycznie - przekształcają zgodę rządzonych w pu-

${ }^{18}$ J. Gray, Berlin, Oakeshott i Oświecenie, w: tegoż, Po liberalizmie, Warszawa 2001, s. 408. P. Franco, Michael Oakeshott as Liberal Theorist, „Political Theory”, vol. 18, nr 3, 1990, s. 414.

${ }^{19}$ T. Hobbes, Lewiatan..., s. 84-85.

${ }^{20}$ Tamże, s. 113.

${ }^{21}$ N. Gładziuk, Druga Babel. Antynomie siedemnastowiecznej angielskiej myśli politycznej, Warszawa 2005, s. 266.

${ }^{22}$ Zgadza się z tym również Leo Strauss pisząc: „[Hobbes - przyp. M.P.] uczciwie uczynił bezwarunkowe prawo naturalne podstawą wszelkich naturalnych obowiązków; obowiązki mają zatem charakter tylko warunkowy". L. Strauss, Prawo naturalne w świetle historii, Warszawa 1969, s. 168-169.

${ }^{23}$ M. Oakeshott, O postawie konserwatywnej, w: tegoż, Wieża Babel..., s. 197.

${ }^{24}$ P. Franco, Michael Oakeshott..., s. 414.

${ }^{25}$ N. Gładziuk, dz.cyt., s. 475-476. Oczywiście, co znamienne, dla Oakeshotta idea taka nie mogłaby zaistnieć bez odpowiedniej praktyki społecznej, postępującej z wolna indywidualizacji wspólnoty, opisywanej chociażby przez J. Burchardta. Zob. M. Oakeshott, Masy w demokracji przedstawicielskiej, w: tegoż, Wieża Babel..., s. 148-151. 
sty abstrakt, pozbawiony realności i witalności ${ }^{26}$. Powołanie władzy to samo w sobie moment przełomowy, kiedy słaba, krucha i zagrożona przez innych jednostka, zrzeka się swojej autonomiczności na rzecz państwa. Władzy zatem nie można obciążać nadmiernymi zadaniami, ani przypisywać jej szeroko zakrojonych funkcji. Budowanie rozbudowanych konstrukcji jest niepotrzebnym ustępstwem na rzecz politycznego rozumu. Może tylko prowadzić do powrotu racjonalizmu politycznego $\mathrm{w}$ nowej, gorszej formie, bo wyposażonego w o wiele większy potencjał ujednolicania i tłamszenia nowożytnej indywidualności. Nie każda władza musi niszczyć indywidualność, ta umiarkowana i oparta na zgodzie rządzonych nie jest dla niej zagrożeniem. Człowiek Hobbesowski jest przez Oakeshotta postrzegany nie tylko jako jednostka kierowana zwierzęcym strachem o własne życie i pożądaniem bezpieczeństwa, lecz również naturalnym pragnieniem mocy, ambicją, honorem i wspaniałomyślnością ${ }^{27}$. To Hobbes jest właśnie rzeczywistym miłośnikiem wolności i ludzkiej indywidualności, w przeciwieństwie do Locke’a który formalizuje osiągnięcia przełomu nowożytnego ${ }^{28}$ i zamyka je $w$ nazbyt racjonalistyczne abstrakty.

Indywidualność człowieka - w odróżnieniu od Locke'owskiego sformalizowanego, pozbawionego podstawy etycznej indywidualizmu, sprowadzającego się we współczesnej praktyce do samoizolacji i społecznego atomizmu - jest osiągnięciem historycznym, a raczej historyczną dolą ludzi nowożytnych. Zatem zadaniem współczesnej filozofii polityki jest analiza stosowna dla doświadczenia nowoczesności, ponieważ bycie filozofem polityki jest głęboko zależne zarówno od rozumienia jej historii, jak i rozumienia historii ludzkości w ogóle. Dziś więc wartościową może być tylko taka myśl, która bierze pod uwagę fakt istnienia jednostki i potrafi cieszyć się jej indywidualnością, ponieważ stanowi to naszą rzeczywistość, naszą historyczną skłonność.

Indywidualność jest zarówno nowożytną przygodnością, jak i ideałem etycznym Oakeshotta. Nie podziela on uproszczonego Berlinowskiego podziału wolności na negatywną i pozytywną, obecnego w myśli Hobbesa

\footnotetext{
${ }^{26}$ Oakeshott, nie wnikając w szczegóły, uważa po prosu, że władza powinna korespondować z indywidualnymi wyborami i wolą rządzonych. Rząd powinien ją chronić i w istocie jest dla niej naturalną ochroną, ponieważ historycznie pierwsze pierwiastki nowożytnych teorii władzy i rządu pojawiają się $\mathrm{w}$ tym samym okresie, co proces wyodrębniania ludzkiego indywidualizmu i wyłaniania się ze wspólnoty ludzkiej jednostki.

${ }^{27}$ M. Oakeshott, The Moral Life in the Writings of Thomas Hobbes, w: tegoż, Hobbes on Civil Association, Indianapolis 1975, s. 87-88, 132. Tenże, Leviathan: a Myth, w: Tamże, s. 163.

${ }^{28}$ Tenże, Introduction to Leviathan, w: Tamże, s. 14.
} 
analogicznego pojęcia wolności jako braku zewnętrznych barier ${ }^{29}$. Poddaje krytyce, również Hobbesowską, separację woli i myśli - sprowadzenie woli do żądzy, do biologicznej chęci, impulsu, wyniku cielesnych napięć i pragnień. Człowiek mimo wszystkich swoich ograniczeń jest istotą myślącą, odznaczającą się świadomością refleksyjną, podejmującą wysiłek namysłu nad swoim postępowaniem, nawet jeśli nie zawsze jest to jasne dla niego samego i dla otoczenia ${ }^{30}$. Postępowanie ludzkie jest wolne, ponieważ choćby częściowo - Oakeshott pozostaje wszak sceptykiem - jest wynikiem ludzkiej inteligencji. Wolność jednak nie jest tożsama $\mathrm{z}$ indywidualnością, jest tylko warunkiem koniecznym, acz niewystarczającym do tego, co można nazwać samookreśleniem, samostanowieniem, autonomią ${ }^{31}$. Nawet jeśli człowiek porusza się w sferze przed-sądów, zaś moralność jest sferą habitualną, ukształtowaną $\mathrm{w}$ drodze socjalizacji, to dostarczają nam one tylko reguł, nie mówiących co począć w konkretnej i zawsze wyjątkowej sytuacji, lecz wskazujących na ewentualne konsekwencje podjęcia takiej, a nie innej decy$\mathrm{zji}^{32}$. „Życie społeczne - życie ludzi - jest wiedzą o tym, że pewne kierunki aktywności pragnienia są pochwalane, a inne potępiane, że niektóre są słuszne, a inne niesłuszne" ${ }^{33}$. Taka podpora jest konieczna, a gwałtowne z nią zerwanie może przynieść opłakane skutki, nie dlatego, iżby oparcie się na tradycji miało być wcieleniem wiecznego ideału postępowania czy prowadziło nas ku prawdzie, lecz dlatego, że ostatecznie nic pewniejszego niż tradycja nam nie pozostaje. Ludzkie postępowanie zawsze jest zabarwione elementem napięcia między tym, jak jest, a tym, jak chcielibyśmy, by było. Jest ono sprawą wierzeń, rozumień i społecznych znaczeń. Człowiek zawsze jest skazany na pewne tajemnice i niepewność doświadczenia, na jego gmatwaninę i różnorodność, poczucie braku pewnej klarowności i ładu. Tym, którzy to ignorują Oakeshott przypisuje „gnostycki typ umysłowości” ${ }^{34}$.

Przejawia się to w ludzkich praktykach. Praktyki to wszelkiego rodzaju sposoby zachowania, zwyczaje, konwencje, zasady, reguły, które kwalifikują ludzkie działania. Praktyki „moralne” w odróżnieniu od celowych,

\footnotetext{
${ }^{29}$ Z. Stawrowski, Prawo naturalne a ład polityczny, Kraków-Warszawa 2006, s. 143. O problemie woli i wolności u Hobbesa por. R. Tokarczyk, Hobbes, Warszawa 1987, s. 116-119.

${ }^{30}$ M. Oakeshott, On Human Conduct, Oxford 1975, s. 89.

${ }^{31}$ Tamże, s. 36-37.

${ }^{32}$ Oakeshott opisując dwa typy idealne moralności: (1) opartą na obyczaju, przyzwyczajeniu afektów i zachowań i (2) osadzoną na kryterium moralnym, którego zastosowanie poprzedza refleksja, jako rzeczywiste widzi różnorodne mieszanki obu z nich. Za pożądaną postrzega jednak oczywiście tę, w której dominuje skrajność pierwsza. M. Oakeshott, Wieża Babel, w: tegoż, Wieża Babel..., 221-242.

${ }^{33}$ Tenże, Postępowanie racjonalne, w: tegoż, Wieża Babel..., s. 113.

${ }^{34}$ Tenże, Racjonalizm w polityce, w: tegoż, Wieża Babel..., s. 22.
} 
transakcyjnych mają charakter nieistrumentalny. Przyjemności z ich praktykowania nie czerpiemy z powodu zaspokajania jakichkolwiek substancjalnych życzeń, lecz angażujemy się w nie tylko ze względu na samo uczestnictwo. Nie są one oparte na naturalnych, biologicznych czy psychologicznych skłonnościach, lecz na wzajemnym zrozumieniu. Nie determinują one naszych wyborów i wyników działań, lecz tylko towarzyszą indywidualnym decyzjom. Praktyka moralna jest jak język, jest instrumentem zrozumienia i nośnikiem wzajemnych kontaktów. Moralność ma zatem całkowicie potoczny i lokalny charakter.

\section{Zawężenie obszaru polityki i stowarzyszenie obywatelskie}

Z tego wyciąga Oakeshott daleko idące zawężenie obszaru polityki ${ }^{35}$. Postrzega on działalność polityczną - rządzenie jako chronienie, a w razie potrzeby dostarczanie, pewnych ogólnych zasad postępowania, czyli tworzenie warunków, w których przy możliwie małych oporach obywatele mogą zajmować się tymi aktywnościami, które sami sobie wybierają ${ }^{36}$. Natura ludzka, jeżeli w ogóle możemy mówić o czymś takim, jest na tyle wątła, iż nie sposób wyciągać z niej pierwszych zasad organizujących wspólne życie ${ }^{37}$. Nie powinno opierać się ono też na silnych przekonaniach religijnych, na przykład na wierze w poznawalne doświadczalnie prawo naturalne, na ładzie opatrznościowym, będącym odbiciem zamiarów Boga w naturze i ludzkiej historii, którego ludzie nie mają prawa pogwałcić bądź też na organicznej teorii społeczeństwa. Punkt wyjścia - jak ujmuje to Oakeshott - nie pochodzi od niebios, lecz od tego, jacy dziś jesteśmy ${ }^{38}$.

Życie w epoce nowożytnej uległo daleko idącej pluralizacji. Ludzie dysponują różnymi pomysłami na życie, realizują zmienne i różnorodne działania. „Nie jest istotne, dlaczego tak się rzeczy mają. Wcale tak być nie musi. (...) Jest to kondycja nabyta, choć nikt jej nie zaprojektował ani nie wybrał świadomie spomiędzy innych. Nie jest ona produktem «natury ludzkiej» puszczonej wolno, lecz istot ludzkich popychanych przez nabyte upodobanie do samodzielnego dokonywania wyborów"39. Zatem pojawienie się

\footnotetext{
${ }^{35}$ S. Wolin, The Politics of Self-Disclosure, „Political Theory”, vol. 4, nr 3, 1976, s. 321-334.

${ }^{36}$ M. Oakeshott, 0 postawie..., w: tegoż, Wieża Babel..., s. 207-208.

${ }^{37}$ Stosunek Oakeshotta do pojęcia natury ludzkiej wydaje się jednak niespójny. Mimo, że często krytykuje zasadniczo uniwersalistyczne liberalne teorie, sam proponuje pewną antropologię, i choć podkreśla jej zmienność i plastyczność - określa ją kontekstem, pozwalającym przypuszczać, iż uznaje ją za charakterystyczną dla całej europejskiej nowożytności. Wątpliwości te przenoszą się na jego koncepcje polityki.

${ }^{38}$ M. Oakeshott, O postawie..., w: tegoż, Wieża Babel..., s. 207-208.

${ }^{39}$ Tamże, s. 209.
} 
indywidualizmu (a raczej ludzkiej indywidualności, jak woli wyrażać się Oakeshott) w tym ujęciu jest raczej bezstronną konstatacją dotyczącą nowożytnej rzeczywistości, a nie ideologicznym postulatem. Nie jest możliwe autorytatywne orzeczenie, czy jest to zasada lepsza i bardziej uszczęśliwiająca ludzkie indywidua niż inny porządek - antyczny czy średniowieczny ${ }^{40}$. Ale to ona jest właśnie rdzeniem naszego istnienia, jej pojawienie się na scenie dziejów pociągnęło za sobą również położenie nacisku na wolność, prywatność, różnorodność, samodecydowanie, więc powinna również przesądzać o sensie współczesnego pojęcia polityczności. Dlatego Oakeshott opowiada się raczej za dalece formalistycznym ujęciem władzy politycznej, nieaspirującej do zrealizowania wspólnego dobra, sprawiedliwości dystrybucyjnej, partycypacji, równości czy ludzkiej doskonałości. Rząd jest tutaj rozjemcą, którego zadaniem jest ,jedynie rządzenie”. Pierwszorzędną sprawą jest unikanie konfliktów, mogących nadmiernie rozgrzać wspólnotę, doprowadzić do jej rozpadu.

Polityka dla Oakeshotta jest kłopotliwą i dalece wątpliwą sferą aktywności. Jest raczej złem koniecznym niż perspektywą, którą należy przyjmować z radością i aprobatą. Cała sfera bogactwa ludzkiego życia zawiera się raczej $\mathrm{w}$ innych praktykach i aby nie skazić ich wulgarnością działalności politycznej, w epoce nowożytnej należy dokonać starannego ich rozdziału. Angielski filozof $\mathrm{w}$ ogóle nie rozciąga polityki na sferę regulacji praktyk moralnych czy ekonomicznych. Terminy polityczny, cywilny, publiczny używa w stosunku do stowarzyszenia obywatelskiego ${ }^{41}$, bez włączania w obręb tego pojęcia jakiejkolwiek wartości, mającej wynikać z realizacji planu boskiego, ucieleśniania ładu naturalnego czy nawet bycia strażnikiem powszechnie podzielanej moralności. Oczywiście w działalności politycznej, podobnie jak w przypadku indywidualnych wyborów, w obliczu ograniczeń rozumu ludzkiego, należy odwoływać się do doświadczenia przeszłości. Dzisiejszym czasom brakuje szacunku dla tego dziedzictwa i dlatego powinno być ono brane pod uwagę przy tworzeniu reguł prawa. „Refleksja może odsłonić stosowną wdzięczność za to, co jest obecnie dostępne, a zatem też i docenienie daru czy dziedzictwa przeszłości; nie ma tu jednak mowy o czynieniu przedmiotu kultu z tego, co przeszłe i minione" ${ }^{42}$.

\footnotetext{
${ }^{40}$ P. Śpiewak, W strone wspólnego dobra, Warszawa 1998, s. 209. Oakeshott opisując przejście od średniowiecza do nowożytności, z ironią określa stosunki panujące w tej wcześniejszej epoce jako „swojskie ciepło wspólnotowych opresji”. Zob. M. Oakeshott, Masy..., w: tegoż, Wieża Babel..., s. 154.

${ }^{41}$ W. J. Coats, Michael Oakeshott as Liberal Theorist, „Canadian Journal of Political Science”, vol. 18, $\mathrm{nr}$ 4, 1985, s. 773-787.

${ }^{42}$ M. Oakeshott, O postawie..., w: tegoż, Wieża Babel..., s. 191.
} 
Civil association nie jest społeczeństwem celowym, w którym prowadzi się politykę wiary (politics of faith) i które prowadzi do nowożytnego państwa - universitas, zjednoczonego mesjanistycznym, pelagiańskim dążeniem do wspólnego celu. Jest to koncepcja oparta na polityce sceptycyzmu (politics of scepticism), na również nowożytnym państwie - societas, civitas peregrina, „społeczeństwie obcych”, gdzie ustrojem jest nomokracja, a prawa rozumiane są jako zwyczajne praktyczne reguły, pozwalające ludziom działać w ramach jednego organizmu społecznego, współistnieć obok siebie. Członkowie takiego stowarzyszenia nie widzą siebie jako towarzyszy zjednoczonych w dążeniu do wspólnego celu, lecz raczej jako wędrowców, pielgrzymów, podróżujących różnymi ścieżkami, a połączonych takimi samymi warunkami wędrówki. Societas to w pewnym sensie wytwór „umowy”, umowy nierozumianej jak w teoriach kontraktualistycznych, lecz raczej jako sojusz pokoleń, jako kompromis pomiędzy przeszłością, teraźniejszością a przyszłością. Jednak umowy, determinującej tylko reguły gry wewnątrz zbiorowości, w której państwo jest tylko arbitrem, a nie dyktatorem mody; umowy, która nie determinuje substancjalnego dobra, do którego obywatele powinni dążyć, do realizacji którego rząd winien ich wdrażać lub z którego należałoby zaczerpywać wzory obywatelskich cnót. Tylko taka skromna koncepcja państwa ma rację bytu w naszej „wolnościowej” rzeczywistości, tylko taka pozwala im dziś przetrwać. Nowoczesne państwo od początku „w większości przypadków było sztuczną konstrukcją złożoną z bardzo zróżnicowanego materiału ludzkiego: różnych osób i różnorodnych wspólnot tych osób, w większości wzajemnie sobie obcych, bez wspólnej przeszłości, różniących się wierzeniami, zróżnicowanych w swych potrzebach, goniących wspólnie, ale za bardzo szeroką gamą odmiennych celów - i w ten sposób wyjątkowo silnie pozbawionych skłonności do zgody na jakikolwiek wspólny, substancjalny cel. I tak pozostało do dziś"43.

Reguły prawne - niebędące ucieleśnieniem sprawiedliwości - ius, lecz przejawem i narzędziem praworządności - lex, są rudymentarnym elementem koncepcji polityki Oakeshotta ${ }^{44}$. Można sobie co prawda wyobrazić władzę zapobiegającą konfliktom społecznym poprzez doraźne mediowanie tzn. namówienie różnych stron konfliktu do ustępstw i zawarcia kompromisu, jednak przy wielkości i różnorodności współczesnych społeczeństw byłoby to zapewne dalece nieefektywne. Dlatego tak ważne są reguły (rules) będące najlepszym wynalazkiem pozwalającym w sposób czytelny regulować

\footnotetext{
${ }^{43}$ Tenże, On Misunderstanding Human Conduct: A Reply to My Critics, „Political Theory”, vol. 4, nr 3, 1976, s. 366.

${ }^{44}$ P. Śpiewak, Granice..., w: M. Oakeshott, Wieża Babel..., s. 10. Por. J. L. Auspitz, Individuality..., s. 279-280.
} 
istnienie wspólnoty politycznej. Nie mają one w praktyce być ucieleśnieniem zasad lub zbiorem niedyskutowalnych algorytmów działania jednostek, czyli sztywną konstrukcją, szkieletem idealnego państwa stworzonym podług zaleceń racjonalistycznych technokratów ${ }^{45}$. Prawo każdemu tworzy jedynie przestrzeń dla „wielkiej przygody przeżywania własnego życia” - i nie ma żadnych innych celów niż tę przestrzeń chronić. Polityka i legislacja koncentrować się powinny tylko na kondycji i autorytecie reguł prawa, stopniu ich przestrzegania, a nie na proponowaniu czy nawet analizowaniu różnych modeli ludzkiego postępowania. $\mathrm{W}$ ten sposób Oakeshott próbuje łączyć wizję polityki jako sztuki uczestniczenia w ustalaniu „wspólnego dobra”, jednak o stosunkowo zawężonym znaczeniu - tutaj: reguł działania zbiorowości z wymogami wolności i indywidualności współczesnych ${ }^{46}$. W tym sensie sfera polityki, prawo i idea civil association (stowarzyszenia obywatelskiego) to byty samowystarczalne i nieinstrumentalne.

Tak widziana polityka wymaga paradoksalnie „postawy konserwatywnej", teraz być może nawet bardziej niż kiedykolwiek wcześniej ${ }^{47}$, rozwagi, umiarkowania, dystansu i odrobiny ironii. Akceptacji raczej dla zmian powolnych i ostrożnych, a nie rozkładu czegoś, „co samo w sobie nie zawiera racji dla swego rozkładu" ${ }^{48}$. Dla utrzymania Oakeshottowskiej nomokracji, stosowne będzie przekonanie, że kiedy coś działa dobrze, to zmiany nie są konieczne. Co więcej każda innowacja jest wówczas co najmniej dwuznaczna, ponieważ zysk i strata są zawsze trudne do oszacowania.

\section{Podsumowanie}

Myśl Michaela Oakeshotta nie podlega łatwym klasyfikacjom. Najwybitniejsi znawcy jego dorobku sytuują go jako specyficznego liberała ${ }^{49}$, większość uznaje go za konserwatystę (choć raczej teoretyka, a nie ideologa $)^{50}$, nawet jeśli ostatecznie trudno orzec, które elementy jego myśli są stricte konserwatywne. Inni próbują wybrnąć z tej niezręczności, dzieląc

\footnotetext{
${ }^{45}$ „Jego powierzchnia (racjonalizmu nowożytnego - przyp. M.P.) odbija bez wątpienia światło dawniejszych racjonalizmów, jednakże w głębi ma on właściwy jedynie sobie charakter". M. Oakeshott, Racjonalizm..., w: tegoż, Wieża Babel..., s. 21. Por. A. Szahaj, Racjonalizm, technokratyzm i śmierć polityki, w: tegoż, Zniewalająca moc kultury, Toruń 2004, s. 247-260.

${ }^{46}$ W. J. Coats, Michael Oakeshott..., s. 786.

${ }^{47}$ Oakeshott ubolewa nad rozkładem tradycyjnej „edukacji liberalnej” i pojawianiem się prawdziwie „barbarzyńskich głosów” w „rozmowie ludzkości”. M. Oakeshott, Edukacja polityczna, w: tegoż, Wieża Babel..., s. 59-86.

${ }^{48}$ M. Oakeshott, O postawie..., w: tegoż, Wieża Babel..., s. 193.

${ }^{49}$ W. J. Coats, Michael Oakeshott..., s. 773-787. P. Franco, Michael Oakeshott..., s. 411-436. J. Gray, Oakeshott as a liberal, w: J. Gray, Post-liberalism. Studies in political thought, Nowy Jork-Londyn 1993, s. 40-46.

${ }^{50}$ P. Śpiewak, Granice..., w: M. Oakeshott, Wieża Babel..., s. 19-20.
} 
dorobek Oakeshotta na różne okresy, kiedy jego stanowisko miałoby się jakoby zmieniać.

Nie było moim celem dokonywanie tego rodzaju klasyfikacji czy podziału. Starałem się w swojej pracy uwypuklić podstawowe znaczenie kategorii takich jak indywidualność, wolność, jednostka, stanowiących centralne punkty filozofii angielskiego myśliciela i w rzeczywistości, jako swoiste zworniki, spajających ją w całość. W rzeczywistości wydaje się, że nie ma „kilku filozofii” Oakeshotta, jego myśl w różnych okresach koncentruje się na różnych aspektach ludzkiego życia, ale ostateczna teoria polityczna wyrażona w ostatniej ważnej pracy Oakeshotta On Human Conduct wynika logicznie z jego wizji świata, ludzi i ich działań zarysowanych wcześniej. Jak sam to ujmował, dzieło to stanowiło wreszcie podjęcie próby, „prawie za późno”, złożenia razem jego rozważań o życiu politycznym, którymi zajmował się odkąd pamiętal ${ }^{51}$. Nie jest więc niczym innym niż ponownym przedstawieniem jego dorobku, niczym innym niż usystematyzowaną wariacją na znajome tematy, i jako takie nie dostarcza nowych argumentów czy nie stawia świeżych merytorycznych akcentów ${ }^{52}$.

Oakeshott jest konsekwentny. Z uporem ogranicza sferę polityki, deontologizuje i formalizuje ją, ale nie czyni tego poszukując rozwiązania idealnego, jak ma to miejsce w przypadku dzisiejszego liberalizmu, tylko po to, by zmierzyć się z nieprzekraczalnym doświadczeniem współczesnej rzeczywistości, z ludzką indywidualnością, która nie akceptuje narzucania sobie z zewnątrz jakichkolwiek celów czy zasad. Stąd właśnie rozmowa o konkretnych ludzkich wyborach i wartościach musi odbywać się i dotyczyć raczej poziomu indywidualnego - zachowań, dyspozycji, psychologii, a nie wspólnotowego porządku politycznego.

Jego „dyspozycja konserwatywna nie jest więc czymś, czego należałoby się wstydzić i czemu można by co najwyżej pobłażać w zaciszu prywatności (na przykład, czytając Prousta), lecz jest postawą równie «nowoczesną» jak umiłowanie zmiany"53. Myśl Michaela Oakeshotta wydaje się być głęboko zakorzeniona w nowoczesności, a on sam proponuje pogodzić się z jej dziedzictwem, szukając sobie w niej własnego miejsca.

M A R C I N P O L A K O W S K I

\footnotetext{
${ }^{51}$ H. F. Pitkin, Inhuman Conduct and Unpolitical Theory: Michael Oakeshott's On Human Conduct, „Political Theory”, vol. 4, nr 3, 1976, s. 302.

${ }^{52}$ D. Spitz, A Rationalist Malgre Lui: The Perplexities of Being Michael Oakeshott, „Political Theory”, vol. 4, nr 3, 1976, s. 342-343.

${ }^{53}$ A. Bielik-Robson, Inna nowoczesność. Pytania o wspótczesna formute duchowości, Kraków 2002, s. 148-149. Por. M. Cichocki, Ciagłość i zmiana, Warszawa 1999, s. 60.
} 


\section{Individuality as a category of Michael Oakeshott's philosophy}

Michael Oakeshott is one of the most remarkable English political philosophers of the $20^{\text {th }}$ century, but for many years his work was underestimated. Especially outside the United Kingdom his most important publications were very difficult to find.

In this article, I intend to present Michael Oakeshott's philosophy as the philosophy of individuality, freedom and will, immersed in social practice - these are the most important and central terms of his thought.

Firstly, I try to describe Oakeshott's sceptical view on the nature of philosophy and the rationalist tradition from Plato to modern rationalism. I also write about Oakeshott's view of experience. There are different types of experience which have their own assumptions about the nature of the world and which allow different types of activity to take place. These activities are history, science, practical life and poetry.

Then I try to consider the influence of Hobbes on the Oakeshott's conceptions. Hobbes is one of the most esteemed thinkers in Oakeshott's work. He broke with the philosophical tradition of the West: the tradition of the common good and defining the final aim of the human life in the community. Hobbes is also the first philosopher to put individuality as the basis of human behaviour. Moreover for Hobbes will is the basis of the modern state, political authority and obligation. Will is the master-term of his political philosophy.

Individuality is a humane ideal, referred not to an economic freedom or negative liberty. It is only an accidental historical achievement of modernity, but one should accept it according to its reality, even if human conduct is still deeprooted habitual process, as it has always been. The morality in the modern age is the individual issue, so it must be considered in the conversation between individuals. It is not a favourable or desirable situation, but one ought to accept it as a historical lot.

Oakeshott's conception is a conception of political scepticism. He is a follower of the civil association regime (in the modern age: societas), resisted on the rules of law, where government is only the guarantor of civil peace and individuality. It replaces the conception of community regimes, enterprise society (universitas) - but also by a common purpose, recognised as lofty.

Michael Oakeshott's thought, emphasized on the notion of freedom, individuality or plurality, is deeply ingrained in modernity, even if its aim is to restitute or reformulate it. 